\title{
MACROECONOMIC ANALYSIS AND ITS INFLUENCE ON INTERNATIONAL BUSINESS AND ECONOMIC GROWTH (Study on Indonesian country period 2008-2017)
}

\author{
Gerard A. Tulong, Suhadak, Siti Ragil Handayani \\ Faculty of Administrative Science, University of Brawijaya, Indonesia \\ Email: gerard.tulong@gmail.com
}

\begin{abstract}
ABSTRAK
Tujuan daripada penelitian ini adalah untuk menganalisis secara empiris pengaruh keadaan Makroekonomi terhadap Bisnis Internasional dan Pertumbuhan Ekonomi Indonesia dalam periode tahun 2008-2017. Tingkat Suku Bunga, Tingkat Inflasi dan Nilai Tukar adalah indikator-indikator Makroekonomi. Penanaman Modal Asing, Expor dan Impor sebagai bagian dari Perdagangan Internasional adalah indicator-indikator Bisnis Internasional. Produk Domestik Bruto, pengeluaran sector Privat dan Pemerintah adalah indicator-indikator Pertumbuhan Ekonomi. Penelitian merupakan penelitian eksplanatori dengan pendekatan penelitian kuantitatif. Populasi dan Sampel bersifat time series periode tahun 2008-2017, seluruhnya adalah data sekunder yang diakses pada institusi resmi Bank Indonesia, Badan Pusat Statistik, Badan Koordinasi Pasar Modal, Indonesia National Single Window dan World Bank. Analisa data menggunakan GeSca secara online dan bersifat reflektif. Hasil analisis deskriptif menunjukkan keadaan Makroekonomi, kegiatan Bisnis Internasional dan Pertumbuhan Ekonomi Indonesia. Hasil penelitian menunjukkan bahwa satu variabel memiliki hubungan yang tidak signifikan dan dua variabel lainnya memiliki hubungan yang signifikan. Makroekonomi memiliki hubungan yang tidak signifikan terhadap Bisnis Internasional, Makroekonomi memiliki hubungan yang signifikan dan negatif terhadap Pertubuhan Ekonomi, Bisnis International memiliki hubungan yang signifikan can positif terhadap Pertumbuhan Ekonomi.
\end{abstract}

Kata Kunci: Makroekonomi, Bisnis Internasional, Pertumbuhan Ekonomi, Indonesia.

\begin{abstract}
The research purpose is to empiricaly analyze the influence and importance of Macroeconomic on International Business and Economic Growth in Indonesia period 2008-2017. Interest Rates, Exchange Rates and Inflation Rates are Macroeconomic Indicators. Foreign Direct Investment, Expot and Import activity are International Business Indicators. Gross Domestic Product, Private and Government Consumptions are Economic Growth Indicators. This explanatory research will use quantitative research approach. Population \& Sample are time series data period 2008-2017, all data are secondary data taken from credible institutions as Bank Indonesia, Statistics Indonesia, Burreau of Investment Indonesia, Indonesia National Single Window and World Bank. The data analyzed using GeSca operating system online and signed reflective. The descriptive analysis shown Indonesia's Macroeconomic volatile, International Business Activity and Economic Growth. The research results shown that there are one variable has insignificant effect and two variables has significant effect. Macroeconomic has insignificant effect on International Business, Macroeconomic has negativesignificant effect to Economic Growth and International Business has positive-significant to Economic Growth.
\end{abstract}

Keywords: Macroeconomic, International Business, Economic Growth, Indonesia. 


\section{INTRODUCTION}

"International Business consist of transactions that are devised and caried out across national borders to satisfy the objectives of individuals, companies and organizations" (Moffet, $2011: 5$ ). All companies that engages in business functions beyond its domestic borders known as Multinational Companies or MNC (Cullen, 2010 : 6). The globalizations of the world economies has been expanded opportunity for any Enterprise to access physical and financial capital accumulated in other countries.

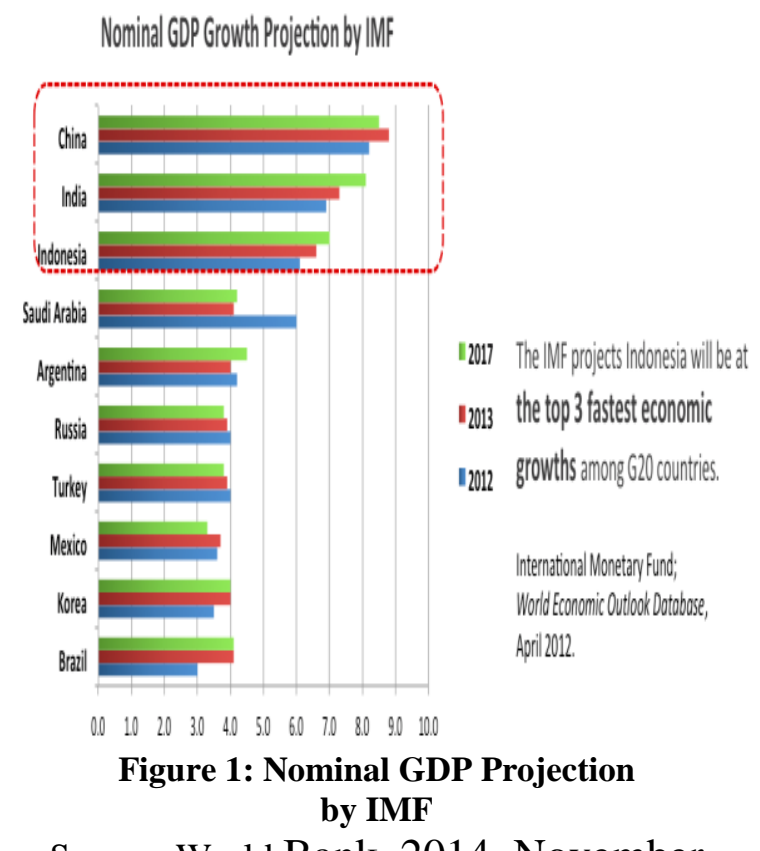

Source: World Bank, 2014, November

The hearth of globalization is increasing trade between companies from different countries. International trade is expected to improve the productivity and the welfare of consumers (Moffet, 2011 : 64). Direct Foreign investment (FDI) is the other option. Expansion has made FDI even more important rather than trade. The lasting interest in an FDI typically involves the establishment of manufacturing facilities, warehouses, bank premises, operation of equipment (such as drilling rigs, construction activities, and expenditure of natural resources) and other permanent operations or relationships.

Emerging country confirmed their positions as motor of economic growth globally (Coface, 2008 : 9). According to
Worldbank publication on 21 April 2017 about country overview, "Indonesia is a diverse archipelago nation of more than 300 ethnic groups, own the largest economy in Southeast Asia. Indonesia has charted impressive economic growth since overcoming the Asian financial crisis of the late 1990s. Today, Indonesia is an emerging middle income country, the world's fourth most populous nation, world's 10th largest economy in terms of purchasing power parity and a member of G-20. Considerable challenges remain in achieving Indonesia's goals". A continued slump in demand for commodities, fuels in the past decade has led to moderating GDP growth.

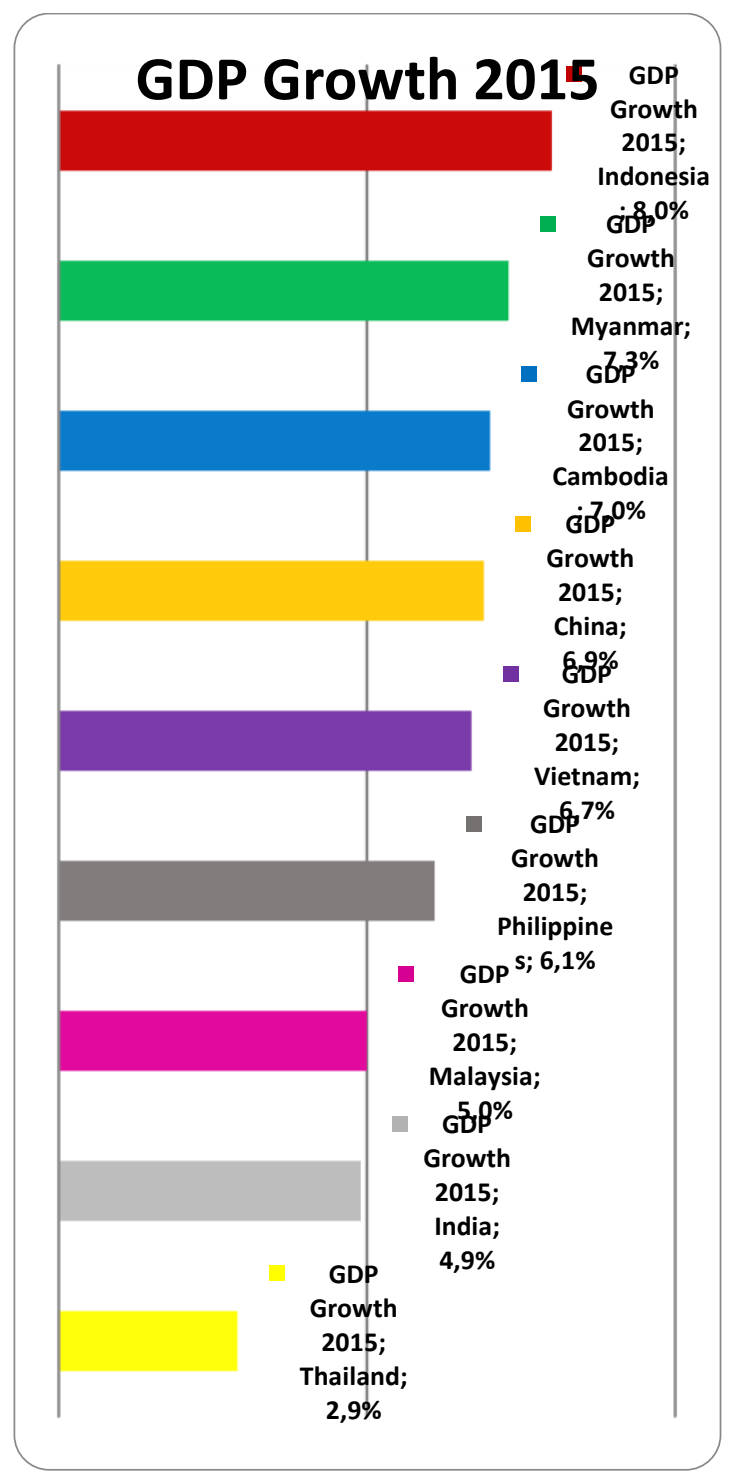




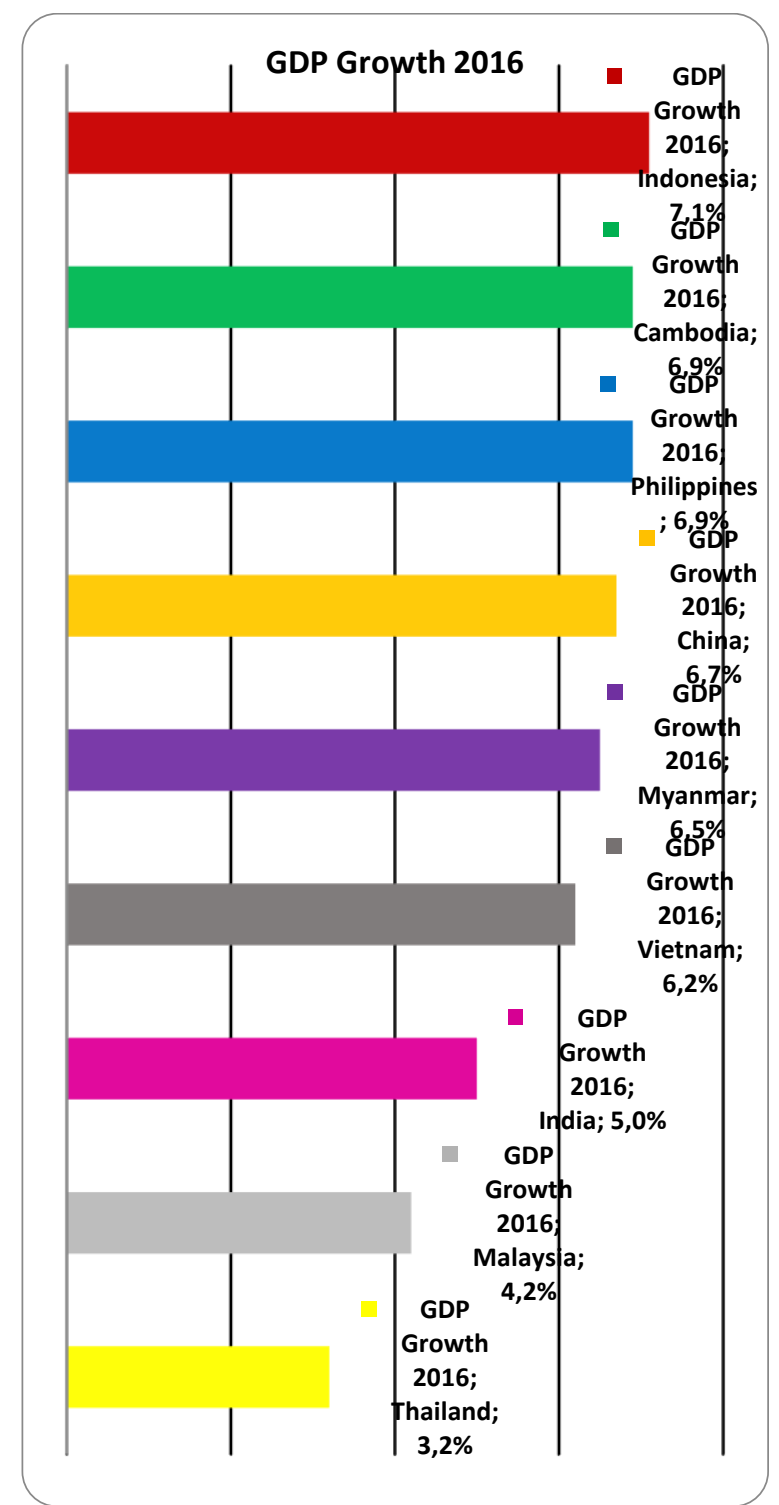

Figure 2: GDP Growth among Asean Countries (2015-2016)

Source: World Bank, 2017, October

Economic Growth was associated with industrialization and export promotion. Many countries have been managed to restructures them self by forming an important link with MNC. These, will result on highly increased flow in trade due to internationalization and globalization. Industrialization will restructure the forms of domestic Firms linkage into MNC's that will provide international mass production. In the same time, industrialization will also open a new opportunity for international trade and business. In figure 2, the last two years, Indonesia has shown extraordinary GDP Growth.Compared to China GDP growth, Indonesia the biggest GDP growth among ASEAN (plus China) countries for 2015 and 2016. A country with high GDP growth will become highlights of investors because there is expectation to give more and high return in the future.

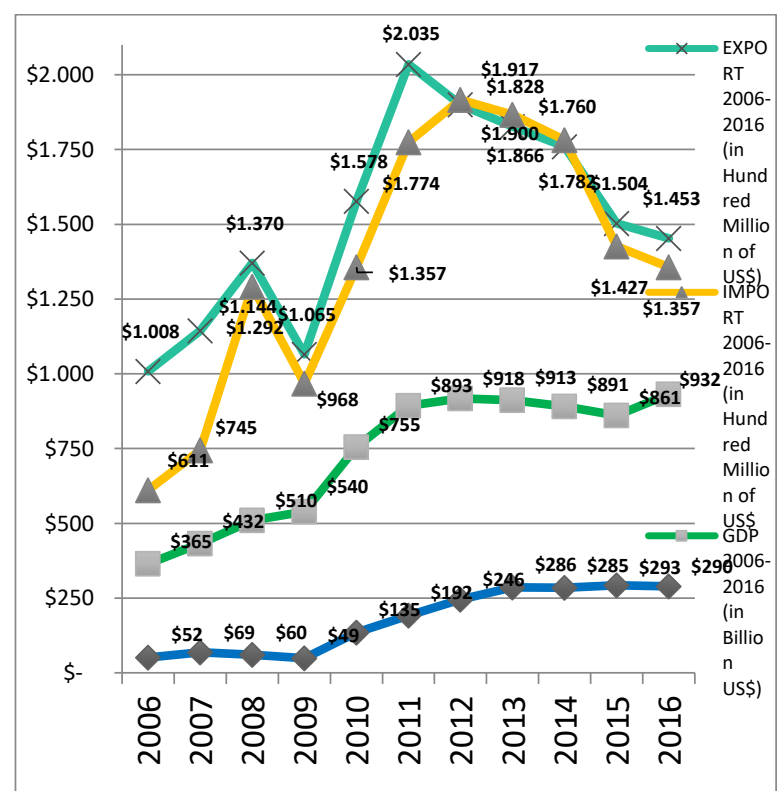

Figure 3: Total GDP and FDI (2006-2016) Source: World Bank, 2017, October

In figure 3, foreign trade activities shows the worse year for Indonesian trade (during the past ten years was on 2006-2016) on 2012 to 2014 when Indonesia has trade deficits, imported goods are more than exported goods. Good news is that the Exported goods begin to bounce up through the imported goods in the middle of 2015 and Indonesia back into trade surplus on 2015-2016. Must highlight that Indonesian exported goods has been decreaseing since 2011 and also followed by Indonesian Imported goods. Indonesian GDP has steadily risen significantly, from $\$ 364.57$ (billion) on 2006 to $\$ 932.26$ (billion) on 2016, it showed a strong improvement on 2016. This is a positive development as it should strengthen purchasing power and therefore to rise the consumption. FDI net inflows shows a little bit declining on 2016 at \$289.64 (hundred million) compared with 2015 at $\$ 293.00$ (hundred million) to 2016 at $\$ 37.62$ (hundred million), even tough the GDP has bounce back to increase on 2016. However, some research in the past did by Alfadel (2012), Ulah and Rauf (2013), Suzana (2014), Raisova and Durcova (2014), Dua and Garg (2015), provided some findings in which mention that International Business is coherent with Economic growth. 


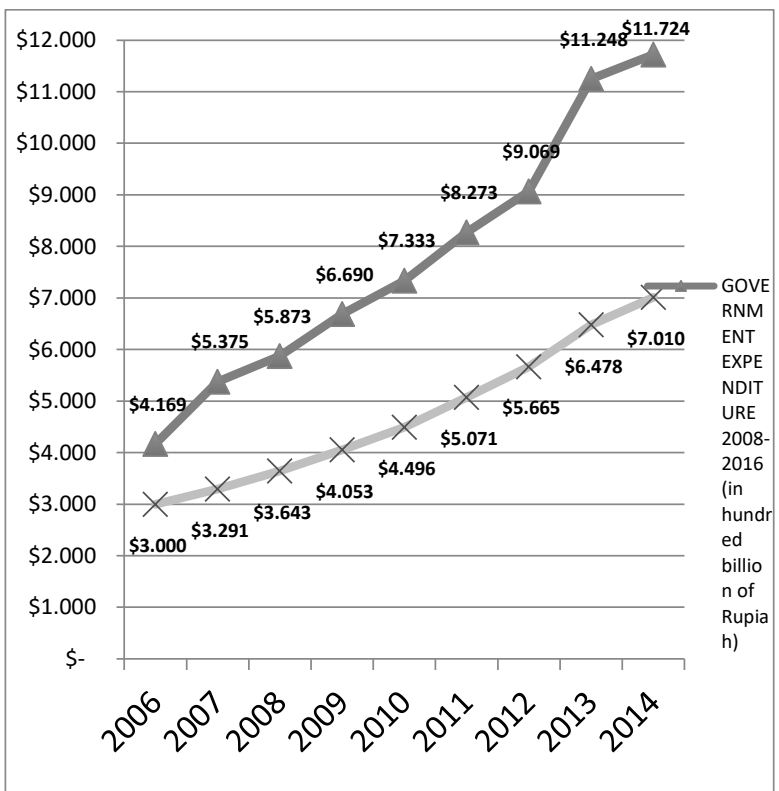

Figure 4: Total Private and Government Spending (2008-2016)

Source: bps.go.id, 2017, October

Economic Growth very well known to be influence by household (private and government) activities, that is why it is very important to finance the expenditure of the households and manage the origin of income. If government tend to do the act of borrowing (especially from the banks) to fund their expenditure, it will stand against private sector, then reducing the private investment. Sometimes, government increase their spending and put the money to the products that private sector can obtain more efficiently. The phenomenon regarding the increase of GDP on 2016 in figure 3 could by partly explained by cooled household consumption in figure 4. The findings of reseach did by Varlamova and Larionova (2015) which mentioned that household spending is a share of Gross Domestic Product. Since the househols activities always increasing year by year. Therefore could be sign that public spending has been more every year and also followed by Gross Domestic Product.

Despite interest rate cuts conducted by the Bank Indonesia on 2016 amid easing inflation and a stable rupiah. This is attributed to low commodity prices. According to Bank Indonesia, "In simple terms, inflation is understood as a persistent, ongoing rise across a broad spectrum of prices. The indicator commonly used to measure the level of inflation is the Consumer Price Index (CPI). Changes in the CPI over time are indicative of price movements for packages of goods and services consumed by the public". Bank Indonesia mention that "Stable inflation is a prerequisite for the sustainable economic growth that will ultimately bring benefits through improvements in public welfare, the importance of inflation control is based on the reasoning that high inflation will lead to steady erosion of people's real incomes and deterioration in living standards so that all members of society and especially the poor sink into deeper poverty". "Unstable inflation will create uncertainty for economic actors, affecting their ability to make decisions. Empirical experience shows that unstable inflation will create added difficulty for the public in their decisions regarding consumption, investment and production, which in turn will hamper economic growth". "A higher level of domestic inflation in comparison to neighbouring countries will make domestic interest rates uncompetitive, which may lead to pressure on the rupiah exchange rate. On the other hand, government has tools to control the economy and macroeconomics issue. The tools are Fiscal policy and monetary policy". Monetary policy usually supported with Interest Rates to manage the Inflation and maintain the Currency in order to stabilize the growth of country's economies.

Research Questions. Based on the description in the research bachground, the research question are:

1. Does macroeconomic influence international business in Indonesia?

2. Does macroeconomic influence economic growth in Indonesia?

3. Does international business influence economic growth in Indonesia?

Research Objectives. Based on the description in the research bachground, the research objective are:

1. To explain the effect of macroeconomic on international business in Indonesia.

2. To explain the effect of macroeconomic on economic growth in Indonesia.

3. To explain the effect of international business on economic growth in Indonesia.

\section{LITERATURE REVIEW}

Macroeconomic. "Economics is the study of how humans make decisions in the face of needs and/or wants for goods, services and resources exceed the supply and what is available". "Macroeconomic is a study of wide phenomena related to the forces and trends that affects the economy as a whole. Macroeconomic deal with the economy as a whole, focuses on the 
determinants of total national output, study national instead of household income, looks to overall instead of individual prices level, it deals with aggregates such as aggregate consumption and investment" (Case, 2012 : 97). Exchange Rate, Interest Rate and Inflation Rate are Macroeconomic indicators. Exchange Rate. "The Exchange Rate defined as the price of one unit of currency in terms of another currency" (Jochumzen, 2010 : 19). "Currency is the paper bills and coins in the hand of the public and should be counted as money" (Case, 2012 : 192). "The Equilibrium exchange rate will change over time as supply and demand schedules changes. Change in demand for a currency or the supply of a currency for sale will affect the equilibrium of exchange rate. The factors that influence the supply and demand of currency are changes in inflation rate, interest rate, income level, government control and expectation" (Madura, 2008 : 97). Inflation Rate. "The percentage change in the price level defined as Inflation. Inflation also considered independent of which year we use as our base year for our price index, price index usually calculated at a particular of time, inflation over a time period, typically one year" (Jochumzen, $2010: 59-65$ ). "The inflation rate is measured as the percentage change in the Consumer Price Index. Inflation is equal to the growth rate of money. Quantity of money available determines the price level and that the growth rate in the quantity of money available determines the inflation rate. On the other hand, Inflation is like a tax because everyone who hold the money loses thieir purchasing power of goods and services" (Jochumzen 2010 : 73). "Regarding the period time of inflation, the firms must changes their prices more often, to maintain their margin and avoid loss". Interest Rate. "Interest Rate is commoly expressed as a percentage of size of the loan per unit of time, typically per year" (Jochumzen, 2010 : 45). "Central Bank is an institution designed to oversee the banking system and regulate the quantity of money in the economy" (Case, 2012 : 200). "Central Bank has monopoly on issuing the national currency and the primary responsibility of Central Bank is to maintain the stable national currency for a country, stability is something specified in terms of inflation and/or growth rate in the money supply" (Jochumzen, 2010 : 40). "In most country, central bank is responsible for monetary policy, by monetary policy, the central bank directed at controlling money supply and the interest rates" (Jochumzen, 2010 : 48). "Bank Indonesia as an independent central bank was initiated by the UU No. 23/1999 on May 17, 1999 and has been amended with UU No.3/2004 on January 15, 2004". "As an independent state institution, Bank Indonesia is fully autonomous in formulating and implementing each of its task and authority as stipulated in the Act". "Bank Indonesia strengthened monetary operations by introducing a new policy rate known as the BI 7Day (Reverse) Repo Rate, effective from 19th August 2016". "In addition to the existing BI Rate, the new policy rate does not represent a change of monetary policy stance". International Business. "Company engages in international business when it conducts any business functions beyond its domestic borders" (Cullen, $2010: 7$ ). "The words across national boundaries are the key difference between international business and domestic business. International business can be broken down into four types: foreign trade, trade in services, portofolio investments and direct investments" (Ajami, 2014 : 4). "Primary types of international business are foreign trade and foreign direct investment, the entry mode to international business could be vary such as: international trade, licensing, franchising, joint ventures, acquisitions, and plant establishment" (moffet, 2011 : 05). Export, Import and Foreign Direct Investment are International Business indicators. Export and Import activity as part of Foreign Trade Practices. "Trade is a relatively conservative approach that can be used by firms to penetrate markets by exporting or to obtain supplies at low cost by importing, this approach entails minimal risk because the firms did not place any of its capital at risk" (Madura, 2008 : 7). They can use their websites to sell (export) the product wide world and the buyer (importer) can find what they need online trough the internet. "The definition of Export is goods and services that are produced domestically and sold abroad, in other hand import can be describes as goods and services that are produced abroad and sold domestically" (Case, 2012 : 102). Foreign Direct Investment. "The establishment or expansion of operations of a firm in foreign contry (like all investment, it assumes a transfer of capital) can be defined as Foreign Direct Investment" (Moffet, $2011:$ 12). The motives of FDI can be speciffiied into two perspectives. First, Revenue-Related motives which encourage FDI to explore new sources of demand. Second, Cost-Related motives which 
efforts the MNC to reduce cost and operate efficiently.

Economic Growth. "Economic growth can be illustrated by an outward shift of the productions possibilities frontier" (Mankiew \& Ghent, 2009 : 23). "The standard living in an economy depends on the abilities of an economy to make goods and services" (Mankiew \& Ghent, 2009 : 226). "Productivity can be defined as the amount of goods and services a worker produces in each hour of work". Furthermore, Productivity inits turn, has an important role to increase economic growth rate in a nation (Mankiew \& Ghent, 2009 : 226). Private and Government Expenditure as Household activities and Gross Domestic Product are Economic Growth indicators. Private and Government Expenditure as part of Household Activity. "Household are buyers in the market for goods and services and sellers in the market for factors of production" (Mankiew \& Ghent, 2009 : 21). "Total consumptions by the private sector need not be equal to disposable income as private sector can save and borrow" (Jochumzen, 2010 : 30). Private Consumption spending includes buying food and buying clothes (Mankiew \& Ghent, 2009 : 21). "Government purchases is the total spending on goods and services by local, state, and federal governments" (Mankiew \& Ghent, 2009 : 317).

"Government consumption spending includes paying workers to administer government programs" (Mankiew \& Ghent, 2009 : 317). Gross Domestic Product. "GDP is defined as the market value of all finished goods and services produced by in a country during a certain period of time" (Mankiew \& Ghent, 2009 : 200). "To judge whether or not an economy is doing well, it is usefull to look at Gross Domestic Product. Higher GDP can be also a signal of economic performance, higher GDP means the total wealth of the country is increasing over time. GDP also as a flow variable not as a stock variable, flow variable can be measured in something per unit of time" (Mankiew \& Ghent, 2009 : 200). "GDP did not measure the total wealth of a country, but a measure of the income of the country during a certain period of time" (Jochumzen, $2010: 23$ ).

\section{CONCEPTUAL FRAMEWORK}

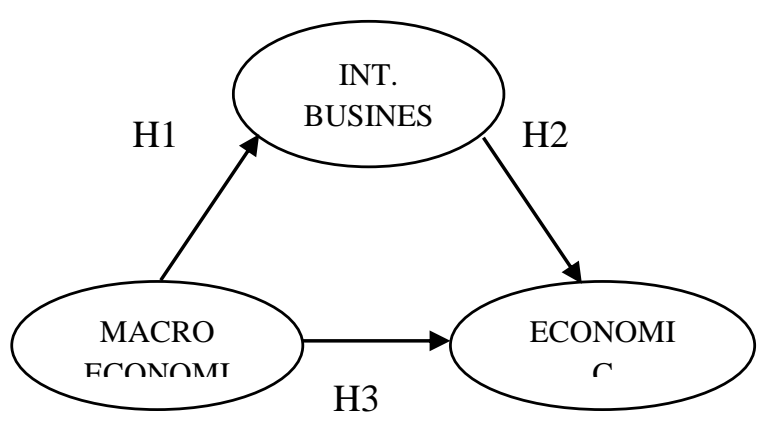

Figure 5: Conceptual Model

Source: Processed

Conceptual Model. Economic Growth (which will be measured by Private Spending, Government Spending and Gross Domestic Product), International Business (which will be specifficly measured by Foreign Direct Investment, Export and Import), both as dependent variables will be influenced by Macroeconomics Factors (Inflation Rate, Interest Rate and Exchange Rate) as Independent Variables. In other considerations, Economic Growth as Dependent variable will be influenced by International Business as well.

Hypothesis Model. Hypotheses can be also known as temporary answers to research questions that must be proven (Sugiyonoo, 2008 :93). "Predictions the researcher makes about the expected relationships among variables can be called Hypotheses" (Creswell, 2009 : 132). "Predictions the researcher makes based on prior literature and studies to suggest potential outcome can be called Directional Hyphotheses" (Creswell, 2009 : 134). Directional hyphotheses will be used due to the predictions made in this research are based on previous research and assumption could become a potential output.

$\mathrm{H}_{1}$ : Macroeconomics affects International Business in Indonesia.

$\mathrm{H}_{2}$ : Macroeconomics affects Economics Growth in Indonesia.

$\mathrm{H}_{3}$ : International Business affects Economic Growth in Indonesia.

\section{RESEARCH METHOD}

Research Type. Research type that used in this research is explanatory research. In order to explain the relationships between independent and dependent variables, the researcher choose explanatory research. In this research, researcher will use quantitative method because mostly the 
data in this research is numeric which will be processed with specific research tools.

Research Location. This research will be held at the official website of Bank Indonesia, Statistics Indonesia, Burreau of Investment Indonesia, Indonesia National Single Window and World Bank based on consideration that the websites provide many data regarding country overview, including Macroeconomics sector, International Business and Economic Growth.

Population and Sample. In this research, researcher will use saturated sampling technique, which used if all the member of population will be used as samples. Mostly this kind of practice happened when the population is relatively small, bellow thirty. Or, the research wants to generalized with minimum error rate (Sugiyono, 2008 : 122-123). Populations and sample of this of this research is equal to 38 (10 years $\mathrm{x} 4$ quarter).

Table 1: Variables, Indicators, Symbol and Measurement

\begin{tabular}{|c|c|c|c|}
\hline VARIABLE & INDICATOR & SYMBOL & MEASUREMENT \\
\hline \multirow{3}{*}{$\begin{array}{c}\text { MACRO } \\
\text { ECONOMIC } \\
\left(\mathrm{X}_{1}\right)\end{array}$} & Interest Rate & SBI & Percentage (\%) \\
\hline & Inflation Rate & INF & Percentage $(\%)$ \\
\hline & Exchange Rate & CUR & IDR/USD \\
\hline \multirow{3}{*}{$\begin{array}{c}\text { INT. } \\
\text { BUSINESS } \\
\left(\mathrm{Y}_{1}\right)\end{array}$} & Export & EXP & Million of USD \\
\hline & Import & IMP & Million of USD \\
\hline & $\begin{array}{l}\text { Foreign Direct } \\
\text { Investment }\end{array}$ & FDI & Million of USD \\
\hline \multirow{3}{*}{$\begin{array}{c}\text { ECONOMIC } \\
\text { GROWTH } \\
\left(\mathrm{Y}_{2}\right)\end{array}$} & Private Spending & PVT & Billion of IDR \\
\hline & $\begin{array}{l}\text { Government } \\
\text { Spending }\end{array}$ & GVM & Billion of IDR \\
\hline & $\begin{array}{l}\text { Gross Domestic } \\
\text { Product }\end{array}$ & GDP & Billion of IDR \\
\hline
\end{tabular}

Source: Bank Indonesia, World Bank, Badan Pusat Statistik Indonesia (Processed)

Research Variables. In this research, Macroeconomics as independent variable can be measured by the Interest Rate, Inflation Rate and Exchange Rate. Dependent Variables in this research are International Business and Economic Growth. International Business as dependent variable can be measured by Export, Import and Foreign Direct Investment. On the other hand, Economic Growth as dependent variable can be measured by Private and Government Spending, also Gross Domestic Product.

Types and Source of Data. This research used secondary data. Secondary data obtained indirectly and mostly formed by many data to be processed by credible institutions. This research using time series data over period of ten years, started from 2008 to 2017.

Methods of Collecting Data. The data can be accessed through www.bi.go.id and also world.bank.go.id. the websites provide many data regarding country overview, including Macroeconomics sector, International Business and Economic Growth.

Methods of Data Analysis. This research is to analyze the effect of macroeconomic on international business and economic growth in Indonesia by using Generalized Structured Component Analysis (GSCA). According to Ghozali (2008) GSCA can be seen as component based Structural Equation Model (SEM), which its variable defined as a component of observed variable. In GeSCA operational system, the indicators will be assigned reflective to explain the relationship within variables. The model made using GeSCA operating system online (figure 8). In GeSCA, the evaluation using Outer Model, Inner Model and FIT Model. Loading Factors of Indicators within Variables. This research uses loading factor to measure the significance of the indocators. The larger size of loading factor the more important the indicator reflected the variable. It said by Ghozali (2008), for the first stage in a research of measurement scale development, 0.50 to 0.60 can be considered sufficient value to indicate that latent construct is good. The scale to estimate the loading Value is from 0 to 1. Hypothesis Testing using GSCA. This research uses path coefficient to measure the relationship within variables. It said by Hwang (2010) that "boothstrap Critical Ratio (CR) is used for testing the significance of an Estimate". According to Ghozali (2008), "CR more than 1.96 can be used to defined and describe the Estimate results of variables".

\section{RESULTS AND DISCUSSIONS}

Loading Factors within Macroeconomic Indicators. Table 2 shows that Inflation Rate (INF) has 0.814 loading value and Interest Rate (INT) has 0.808 loading value, which is means these two indicators considered practically significant to reflect Macroeconomic variable. While on the other hand, Exchange Rate (CUR) is insignificant to practically reflect macroeconomic variable because having only 0.570 for loading value, thus can not be considered. 
Table 2: Loading Factor within Macroeconomic Indicators

\begin{tabular}{|c|c|c|c|}
\hline \multirow{2}{*}{ INDICATORS } & \multicolumn{3}{|c|}{ LOADING } \\
\cline { 2 - 4 } & ESTIMATE & SE & CR \\
\hline INF & 0.814 & 0.752 & 1.08 \\
\hline CUR & -0.570 & 0.555 & 1.03 \\
\hline SBI & 0.808 & 0.775 & 1.04 \\
\hline
\end{tabular}

Source: GeSCA results, 2018

Loading Factors within International Business Indicators. In Table 3, Export (EXP) has 0.845 loading value, Import (IMP) has 0.889 loading value, and Foreign Direct Investment (FDI) has 0.865 loading value. All indicators are considered practically significant to reflect International Business variable.

Table 3: Loading Factor within International Business Indicators

\begin{tabular}{|c|c|c|c|}
\hline \multirow{2}{*}{ INDICATORS } & \multicolumn{3}{|c|}{ LOADING } \\
\cline { 2 - 4 } & ESTIMATE & SE & CR \\
\hline EXP & 0.845 & 0.033 & 25.7 \\
\hline IMP & 0.889 & 0.023 & 38.38 \\
\hline FDI & 0.865 & 0.175 & 4.93 \\
\hline
\end{tabular}

Source: GeSCA results, 2018

Loading Factors within Economic Growth Indicators. Table 4 shown that Private Spending (PRV) has 0.981 loading value, Government expenditure (GVM) has 0.901 loading value, and Gross Domestic Product (GDP) has 0.987 loading value, which means all indicators considered practically significant to reflect International Business variable.

Table 4: Loading Factor within Economic Growth Indicators

\begin{tabular}{|c|c|c|c|}
\hline \multirow{2}{*}{ INDICATORS } & \multicolumn{3}{|c|}{ Indicators } \\
\cline { 2 - 4 } & ESTIMATE & SE & CR \\
\hline PRV & 0.981 & 0.007 & 144.46 \\
\hline GVM & 0.901 & 0.022 & 40.95 \\
\hline GDP & 0.987 & 0.004 & 238.94 \\
\hline
\end{tabular}

Source: GeSCA results, 2018

FIT Model \& Structural Model. Table 5 shows that this research has 0.626 FIT value, from range 0 to 1 . Which is means $62.6 \%$ of the phenomenon has been explained by the variables in this research model, while the remaining 37.4 is explained by another variables that is not conducted in this research. Larger FIT value indicate more variance is accounted by the model in the research. Adjusted FIT (AFIT) calculate the complexity of the model in to account. Based on table 16, this research has 0.602 AFIT value, from range 0 to 1 . It is means with more complex calculation the variables container in this research model is able to explain $60.2 \%$ of the phenomenon, while the remaining $39.8 \%$ is explained by another variables that is not conducted in this research. The AFIT value in this research value can be used for model comparison.

Table 5: Model FIT

\begin{tabular}{|c|c|}
\hline FIT & 0.626 \\
\hline AFIT & 0.602 \\
\hline GFI & 0.983 \\
\hline SRMR & 0.233 \\
\hline NPAR & 21 \\
\hline
\end{tabular}

Source: GeSCA results, 2018

Table 6: Structural Model

\begin{tabular}{|c|c|c|c|c|}
\hline Path & Estimate & SE & CR & Description \\
\hline $\begin{array}{c}\text { MACROEC- } \\
>\text { INTBUSS }\end{array}$ & -0.365 & 0.374 & 1.91 & Insignificant \\
\hline $\begin{array}{c}\text { MACROEC- } \\
>\text { ECGROWTH }\end{array}$ & -0.621 & 0.589 & 2.0 & Significant \\
\hline $\begin{array}{c}\text { INTBUSS- } \\
>\text { ECGROWTH }\end{array}$ & 0.413 & 0.142 & 2.53 & Significant \\
\hline
\end{tabular}

Source: GeSCA results, 2018

Hypothesis Test of Macroeconomic to International Business. Path coeficients of Macroeconomic to International Business is 0.365 with critical ratio 1.91 based on GeSCA results on Table 6 . Since the critical ratio is less than 1.96 then it can be stated that Macroeconomic has insignificant effect on International Business. It means, Macroeconomic volatile will not affect International business significantly. The result of path analysis on GeSCA shows that Macroeconomic has insignificant effect on International Business. This results is not accordance with hypothesis Macroeconomic affects International Business. Because, there might be another macroeconomic indicators that is not conducted in this research to make the model significant. In regards of the insignificance of the model, this results is not consistent with previous research did by Dua and Garg (2015), which mentioned in the research that Exchange Rate (as indicator of Macroeconomic) is conducive to Foreign Direct Investment (as indicator of International 
Business). This results occurs probably due to Macroeconomic volatile (risk) usually can be avoided and overcome by doing hedging and future contract in the practice of doing International Business. This practice mostly done by Multinational Corporation as the main actor of free trade and this practice is considered as a common practice in International Business.

\section{Hypothesis Test of Macroeconomic to} Economic Growth. Path coeficients of Macroeconomic to Economic Growth is -0.621 with critical ratio 2.0 based on GeSCA results on Table 17. Since the critical ratio is more than 1.96 and the path coefficient value is negative, then it can be stated that Macroeconomic has significant and negative effect on Economic Growth. It means, if Macroeconomic is getting lower, it will lead to higher Economic Growth. The result of path analysis on GeSCA shows that Macroeconomic affect Economic Growth significantly negative. It means, if Macroeconomic is lower, it will lead the Economic Growth to become higher. This result is accordance with hypothesis that Macroeconomic affects Economic Growth. In regards of this significant and negative results, it is consistent with previous research did by Varlamova and Larionova (2015), which mentioned that there are strong relationship between macroeconomic indicators and household expenditure as a share of Gross Domestic Product (as indicator of Economic Growth). Another research that is consistent with the results is the research did by Mohseni and Jouzaryan (2016), which mention that Inflation (as indicator of Macroeconomic) had direct relationship on Economic Growth. However, this research result inconsistent with previous research did by Alavi (2016), even though both model have significant results. Alavi mention that Exchange Rate (as indicator of Macroeconomic) positively related to Gross Domestic Product (as indicator of Economic Growth). This results consistent with Macroeconomic and Economic growth Theory explained by Jochumzen (2010). When the price increase (means the inflation increase), Gross Domestic Product will fall, Interest Rates should increase and could depreciate currency. Interest Rates determines the flow of funds into and from the financial market, higher interest rates will lead to larger flows of fund into financial market and the smaller flows out from financial market. The higher level of GDP respond to the lower interest rates. Hypothesis Test of International
Business to Economic Growth. Path coeficients of International Business to Economic Growth is -0.413 with critical ratio 2.53 based on GeSCA results on Table 17. Since the critical ratio is more than 1.96 and the path coefficient value is positive, then it can be stated that International Business has significant and positive effect on Economic Growth. It means, if International Business increasing, it will be followed by Economic Growth as well. The result of path analysis on GeSCA shows that International Business affect Economic Growth significantly positive. It means, if International Business tend to be increasing, it will be followed by Economic Growth as well. This result is accordance with hypothesis that Macroeconomic affects Economic Growth. In regards of this significant and positive results, it is consistent with previous research did by Alfadel (2012), which mentioned in the research that Foreign Direct Investment (as indicator of International Business) led Growth Policy to increase the overall Exports (as indicator of International Business) and the rates of Gross Domestic Product (as indicator of Economic Growth). Another research that is consistent with the results is the research did by Ulah and Rauf (2013), which mention in the research that Economic Growth is positively affected by Foreign Direct Investment (as indicator of International Business). The results also consistent with Suzana (2014), which mention on the research that Foreign Direct Investment (as indicator of International Business) is a positive force for Economic Growth and Export (as indicator of International Business) encourages Economic Growth. There are also another research did by Raisova and Durcova (2014) that consistent with this result, which mention in the research that Export and Investment (as indicator of International Business) have the most significant influence on Gross Domestic Product (as indicator of Economic Growth). At last, this research also consistent with the research did by Dua and Garg (2015), which mention in the research that Foreign Direct Investment (as indicator of International Business) has conduciv effect on economic performance in a country. This results consistent with Classical Growth Theory associated by Thomas Robert Malthus. Classical Growth Theory mention that technological development could affect the amount of capital and marginal product of labor rises. Thus, Gross Domestic Product can be increases. This results also consistent with Neo-Classical Growth 
Theory associated by Robert Sollow (developed 1960s), which explain that only technological progress that will affect Gross Domestic Product in the long run. The permanent increase in Gross Domestic Product will be obtained when there is a technological development that increases the productivity of labor, which means the continous technological progress is a must. In this case, Technological development and progress is related to the presence of Multinational Corporation. Multinational Corporation is the entity doing the Foreign Direct Invetment which eventually gave technological transfer and as the entity that doing Foreign Trade (export and import) to eventually will increase the productivity of the country by mass production.

Research Limitation. This research model is expected to have at least $80 \%$ contribution to its whole phenomenon. However, this research model contributes only around $60 \%$ to its whole phenomenon. In regards of this research limitation there might be another variables and indicators which is not explained in the model and can be source of interest for another researchers to do research.

Suggestions. It will be better if further research included oil and gold price as the indicators of Macroeconomics to help. It would be better if further research can also analyse another country in ASEAN for comparation to Multinational Corporation in regards of their plan to expansion.

\section{CONCLUSIONS}

The First result shows Macroeconomic has insignificantly affect International Business in Indonesia during period 2008-2017. Multinational Corporation already found some ways to manage their practice to avoid and overcome the macroeconomic volatile and risk. On the other hand, there might be another macroeconomic indicators that is not conducted in this research. Second, Macroeconomic has significantly negative effect on Economic Growth in Indonesia during period 2008-2017. Meanwhile, if Macroeconomic is getting lower, it will lead the Economic Growth to become higher. This results is in accordance with previous research did by Varlamova and Larionova (2015) also Mohseni and Jouzaryan (2016). Last one, International Business has significantly positive effect on Economic Growth in Indonesia during period 2008-2017. Meanwhile, if International Business tend to be increasing, it will be followed by Economic
Growth as well. This results is in accordance with previous research did by Alfadel (2012), Ulah and Rauf (2013), Suzana (2014), Raisova and Durcova (2014), also Dua and Garg (2015)

\section{REFERENCES}

Acemoglu, D. (2010). Introduction to Moderrn Economic Growth. Massacusetts: MIT.

Ajami, R. A., \& Goddard, G. J. (2014). International Business: Theory and Practice. London: M.E. Sharpe, Inc.

Aruoba, S. B. (2011). IMF Working Paper: Globalization, The Business Cycle, and Macroeconomic Monitoring. Washington D.C.: International Monetary Fund.

Cohen, S. D. (2007). Multinational Corporations and Foreign Direct Investment. New Yorkk: Oxford.

Creswell, J. W. (2009). Research Design: Qualitative, Quantitative and Mix Methods Aproaches. California: SAGE Publication, Inc.

Cullen, J. B., \& Parboteeah, K. P. (2010). International Business: Strategy and the Multinational Company. New York: Routledge.

Ease, K. E., Fair, R. C., \& Oster, S. M. (2012). Principles of Macroeconomics. Boston: Pearson Education.

Fung, H. G., Xu, X. E., \& Yau, J. (2008). International Investment: Traditional and Alternative Approaches. Singapore: World Scientific Publishing.

Hung, G. F. (2008). Advances in International Investments. Singapore: World Scientific Publishing.

Jochumzen, P. (2010). Essentials of Macroeconomics. London: Ventus Publishing ApS.

Katsioloudes, M. I., \& Hadjidakis, S. (2007). International Business: A Global Perspective. Massachusetts: Elsevier Inc.

Kehal, H. (2004). Foreign Investment in Developing Countries. New York: Palgrave Macmilan.

Kim, S. H., \& Kim, S. H. (2006). Global Corporate Finance. Victoria: Blackwell Publishing. 
Kose, A., \& Kei, M. Y. (2002). The Trade Comovement Problem in International Macroeconomics. Washington D.C.: International Monetary Fund.

Madura, J. (2008). International Financial Management. Ohio: Thompson.

Mankiw, G. N., \& Ghent, L. (2007). Principles of Macroeconomics. Ohio: Thompson.

Moffet, M. H., Czinkota, M. R., \& Ronkainen, I. A. (2011). International Business. Massachusetts: John Willey \& Sons, Inc.

openstax COLLEGE. (2014). Principlles of Macroeconomics. Texas: Rice University.

Sadono, S. (2010). Makroekonomi: Teori dan Pengantar. Jakarta: Raja Grafindo Persada.

Sugiyono. (2008). Metode Penelitian Bisnis. Bandung: Alfabeta.

Wheelen, T. L., \& Hunger, D. J. (2012). Strategic Management and Business Policy. New Jersey: Pearson.

Zaman, K., Shah, I. A., \& Khan, M. M. (2012). Macroeconomic Factors determining FDI impact on Economic Growth, Vol.1, No.1. South Asian Journal of Global Business and Research, 79-95.

Alavi, S. E., Moshiri, S., \& Sattarifar, M. (2016). An Analysis of the Efficiency of the Monetary and Fiscal Policies in Iran. Procedia Economics and Finance 36 , 522-531.

Du, L. (2015). Corelation Between Government Expenditure and Real Interest Rate. Procedia Economics and Finance 30 , 202-212.

Dua, P., \& Garg, R. (2015). Macroeconomic Determinant of Foreign Direct Investment. The Journal of Developing Areas, Vol.49, No.1.

Blonigen, B. A. (2005). A review of the Empirical Literature on FDI Determinants. Atlantic Economic Journal $33,383-403$.

Mohseni, M., \& Jouzaryan, F. (2016). Examining the Effects of Inflation and Unemployment on Economics Growth. Procedia Economics and Finance36, 381-389.
Raisova, M., \& Durcova, J. (2014). Economic Growth: Suppply and Demand Perspective. Procedia Economics and Finance 15 , 184-191.

Szkuropova, Z. (2014). A Causal Relationship Between Foreign Direct Investment, Economic Growth, and Export for Slovakia. Procedia Economics and Finance $15,123-128$.

Ullah, F., \& Rauf, A. (2013). Impacts of Macroeconomic Variables on Economic Growth. International Journal of Information, Business and Management, Vol.5, No.2.

Varlamova, J., \& Larionova, N. (2015). Macroeconomics and Demographic Determinants of Household Expenditures in OECD Countires. Procedia Economics and Finance $24,727-733$.

Weinhold, D., \& Reichert, U. N. (2001). Causality Test for Cross-Country Panels: A New Look at FDI and Economic Growth in Developing Countries. Oxford Buletin of Economics and Statistics, 63, 2 , 0305-9049.

Werchola, E. (2004). Macroeconomic Effects of Foreign Direct Investment Inflows. Chicago: University of Illinois.

Badan Koordinasi Pasar Modal. (n.d.). bkpm.go.id. Retrieved August 2017, from bkpm.go.id:

http://www.bkpm.go.id/contents/general/ 4/sound-economy\#.UyeXBvmSzk0

Bank Indonesia. (n.d.). bi.go.id. Retrieved August 2017, from bi.go.id: http://www.bi.go.id/id/publikasi/neracapembayaran/Default.aspx

World Bank. (n.d.). worldbank.org. Retrieved August 2017, from worldbank.org: http://search. worldbank.org/all?qterm=fd i\%20indonesia

World Bank. (n.d.). worldbank.org. Retrieved August 2017, from worldbank.org: http://search.worldbank.org/all?qterm=gd p+growth+indonesia \&title $=\&$ filetype $=$ 